\title{
1 A curse over the Andes?
}

\author{
The resource curse approach \\ and institutional change in the \\ Andean region
}

Bettina Schorr and Gerardo Damonte

\section{Introduction}

Endowed with vast and precious reserves, the countries located along the Andean arch have built their economies around the extraction and exportation of natural resources, mostly hydrocarbons and minerals. In many countries, the significance of the extractive sector has always been high. It increased to historically unique levels with the latest global commodity boom in the years 2003 to 2013 that was fueled by Chinese demand and drove prices sky-high for Andean natural resources of the global markets (Hanni et al., 2018; Bebbington, 2012).

This latest boom has profoundly changed the socio-economic landscape of the region. Given the extraordinary influx of rents and capital, all countries achieved notable improvements regarding the reduction of poverty (Cord et al., 2015; Gasparini \& Cruces, 2013; Stampini et al., 2016). Income inequality, which until then had ranked amongst the highest in the world, decreased sharply (López-Calva \& Lustig, 2010; CEPAL, 2019), motivating scholars to speak of a historical moment of equality for Latin America (Fritz \& Lavinas, 2015).

Notwithstanding these notable improvements, scholarship concerned with the resource curse calls for caution when assessing socio-economic and political dynamics in so-called resource economies that depend on the extraction and export of natural resources. In particular, research has shown that in absence of a robust regulatory framework, resource-rich economies will suffer from a series of political and economic pathologies that can erode short-term improvements stemming from windfalls during booms. The expressions of the resource curse may include economic instability and poverty, inflation, authoritarian rule, corruption, and civil strife, among others.

In fact, various studies have found the curse to be raging in the Andean region by causing financial mismanagement, poverty, and social inequalities (Carrillo Hoyos, 2019; Amézquita Zárate, 2014; Hinojosa, 2011; Perry \& Olivera, 2009; Viale et al., 2017) as well as problems arising from the lack of economic diversification (Ducoing et al., 2018; Tello, 2013; Caria, 2017; Viale, 2019; Barja Daza \& Zavaleta Castellón, 2016), even inside the extractive sector (Cisneros, this volume). In addition, several studies show environmental damages and social conflicts as consequences of the extractivist development 
models promoted in the region (Arellano-Yanguas, 2011; Bebbington \& Bury, 2013; Delamaza et al., 2017; Andrade \& Morales, 2007; Ponce \& McClintock, 2014). As a matter of fact, the environmental consequences and social conflicts provoked by resource extraction have been one of the main focal points of scholarship on the Andean countries during the latest boom.

On the other side of the coin, the recent boom also constituted a period of significant institutional change. In particular, positive trends regarding the decrease in poverty and inequality have been attributed partly to the implementation of new redistributive and social policies (Sánchez-Ancochea, 2019). Other institutional changes in the region include the implementation of powersharing institutions like political decentralization and new participatory institutions, new political transparency rules, and novel environmental legislation. All of these changes share the potential to jump-start important social and distributional consequences that are considered capable of leading the societies of the Andean countries towards more stable and peaceful livelihoods in a healthier natural environment. In other words, they hold the potential of avoiding or mitigating the resource curse.

Yet, research has concentrated on the different expressions of the curse and is largely silent on questions of institutional change and performance in resourcedependent states. For the Andean region, only a few studies have explored institutional dynamics during the latest boom period (Dargent, Orihuela, et al., 2017; Damonte et al., 2021; Bebbington, 2012; Orihuela, 2013; Haslam, 2016; Haslam \& Heidrich, 2018). These are single-country studies (Dargent, Orihuela, et al., 2017; Damonte et al., 2021), which concentrate on specific types of institutions (Haslam \& Heidrich, 2018), or focus on empirical developments in isolation without placing them in the context of broader conceptual or theoretical debates regarding institutional dynamics in resource economies (Damonte et al., 2021; Bebbington, 2012; but see Orihuela, 2013; Haslam, 2016; Haslam \& Heidrich, 2018). As a consequence, we still have only a limited understanding of precisely how institutional change capable of avoiding or mitigating the curse takes place, or the factors that affect the effective performance of such institutions.

This book steps into this gap. By drawing on the fertile grounds of the recent institutional developments in the Andes, it addresses the subject of institutional change and performance under the potentially adverse conditions of resource economies and weak public capacities. Studying several countries of the Andean region, the chapters in this book focus on the causes and actors of institutional change and assess the performance of a variety of new institutions adopted to mitigate the pathologies associated with the resource curse. Taken together, the chapters paint a complex scenario in which institutional change was promoted by a variety of actors following different incentives and using different methods. Likewise, they reveal that institutional performance depends on an entire array of factors, both related and unrelated to the specific dynamics of resource economies. 
In the remainder of this introduction, we briefly review the resource curse literature by putting emphasis on the ways in which resource dependency affects institutions in particular. Building on the limited previous scholarship (Orihuela, 2013; Haslam, 2016; Haslam \& Heidrich, 2018), we criticize this perspective for forecasting doom for a wide range of (otherwise dissimilar) countries, namely those that lack a robust institutional framework when the extractive sector starts to boom. We then discuss the literature concerned with institutional analysis, which has only rarely been connected to the discussion on the resource curse (but see Dargent, Orihuela, et al., 2017). In order to build up a comprehensive perspective on the agents that can promote change and the instruments they use, we add to the literature of institutional analysis insights from policy studies and the contentious politics/social movements literature. On this basis, we elaborate a four-field matrix of agents of institutional change. Each field will be discussed briefly with empirical evidence stemming from an external literature review and the new contributions of the chapters of this book. In the subsequent section, we explore institutional performance in the region stressing those factors that constrain the new institutions from reaching their full effect. We finish by clarifying our central concepts-resource curse, institutions, institutional change, and performance-by presenting the objectives of the book, its organization, as well as short summaries of each of its chapters.

\section{The resource curse: maladies and remedies}

What has become to be known as the resource curse rests on the paradoxical observation that resource-rich countries face a very high risk of suffering a whole series of economic and political pathologies: They tend to be cursed by their riches, which seals their fate as chronic economic and political underperformers (Auty, 1993; Sachs \& Warner, 1999). The maladies coming along with the curse can be manifold and include macro-economic effects such as the deterioration of the terms of trade, the balance of payment crises (also known as the Dutch disease), or the erosion of economic sectors others than the extractive one. Resource wealth tends to be associated with unpopular growth, enduring poverty, and social inequalities (Orihuela, 2013). It has also been shown to motivate corruption and patronage (Mahdavy, 1970; Crystal, 1990; Ross, 2001; Caselli \& Michaels, 2013; Andersen \& Aslaksen, 2013; Zhu \& Wu, 2014) as well as conflict and crime, to perpetuate unqualified or autocratic rulers in power (Cuaresma et al., 2010; Andersen \& Aslaksen, 2013; Brunnschweiler \& Bulte, 2008; Brollo et al., 2013) and to reduce democratic quality (Paler, 2013; Luong \& Weinthal, 2009). Recent scholarship has stressed the environmental and health damages resulting from the extensive extraction of natural resources in the territories where it takes place (Gilberthorpe \& Papyrakis, 2015). In a similar manner, coining the concept of a subnational resource curse, scholars have called attention to the fact that the resource curse tends to be uneven and affects 
particularly those subnational units where the resources are found (Paler, 2011; Manzano \& Gutiérrez, 2019).

The resource curse is believed to be rooted in specific state-society relations that lack a robust fiscal pact (Moore, 2004; Karl, 2007): Since rulers do not have to rely on tax payers among the general public in order to obtain money, they have no incentive to act in a transparent and accountable way. Two mechanisms mediate between resource wealth and the different manifestations of the curse: rent-seeking and political myopia. Rent-seeking is motivated by the extensive gains the extractive sector generates. It denotes a behavior of public officials who engage in politics or work in the public sector because it ensures them access to these rents. As a consequence, wealth stemming from the resource sector ends up concentrated in the hands of a few corporate and political actors, with the latter using rents as patronage to stay in power (Robinson et al., 2006).

Political myopia in the context of resource-based economies refers to an observed short-term bias towards the political support of the extractive sector. Governments and decision-makers focus on the sector while simultaneously ignoring its risks, such as the world markets' inherent volatility or the environmental costs it entails (Brollo et al., 2013; Karl, 1997; Kolstad \& Wiig, 2009; Stevens \& Dietsche, 2008). Political myopia prevents economic diversification by impeding investments in other areas that would guarantee a lesser dependence on the resource sector (Karl, 1997; Shafer, 1994). Also, it restricts regulation, which would imply a reduction of the profits of the sector or limit its activities. Rent-seeking and political myopia can be reinforced by private actors as well as by the state. Business has been found to lobby for the perpetuation of the political focus on the sector or bribe politicians into supporting it because it serves their own particular interests (Karl, 2007; Kaup, 2010).

The curse is not an inevitable fate, though, as can be seen in countries like Norway, Canada, or Australia. It rather depends upon the institutional setting in place and its ability to constrain politicians' behavior (Boschini et al., 2007; Karl, 1997; Kolstad \& Wiig, 2009; Lederman \& Maloney, 2009; Mehlum et al., 2006; Robinson et al., 2006; Ross, 1999, 2015; Sarmidi et al., 2014; Tornell \& Lane, 1999). Therefore, some authors argue it should rather be interpreted as an institutions curse (Menaldo, 2016).

As a policy implication of this observation, the literature has established a firm institutions matter argument that underscores the importance of high-quality institutions to avoid the curse (Mehlum et al., 2006). While generally accepted, at least two aspects of this argument remain unresolved: First, there is no consensus as to which institutions matter when, how, and where (Orihuela, 2018). Research has initially focused on economic institutions (such as stabilization funds and other countercyclical measures) able to counter the negative effects of the inherent volatility of the sector and institutions promoting economic diversification (Kurtz \& Brooks, 2011; Gylfason, 2011; Torvik, 2011; Sugawara, 2014).

More recently, the perspective broadened beyond the economic realm and focused on the good governance of the resource sector (Thorp et al., 2012; 
Bebbington et al., 2018). While good governance is often used in an unspecific way, it generally refers to sectoral regulation, fiscal and administrative regulation, distributive and redistributive instruments, transparency and accountability rules, as well as social and environmental provisions (e.g. Cameron \& Stanley, 2017). Systematizing the various streams in this literature, Orihuela (2018) identifies six governance challenges resource-dependent states are facing: macroeconomic management, the local and sectoral economy, the sustainability of economic growth, democracy, environmental justice and community inclusion, and peace. Each of these comes with specific development problems such as the balance of payment crisis, environmental burdens, political anomia, and the growth of an anti-politics machine. In order to tame the curse, a comprehensive institutional framework must address these six government challenges simultaneously.

The second unresolved problem is related. It raises the question as to how these institutions that matter and are good can come into being and perform effectively. This question is of particular importance for those resource-rich non-western, non-industrialized countries lacking robust statehood and democratic quality and featuring high levels of poverty and social inequality - a group that includes the majority of countries labeled as developing. Under these adverse conditions that foster all sorts of deficiencies, the prospects for avoiding the curse are discouraging. Will these countries ever be able to escape it?

While the resource curse theory understands institutions as a remedy for the curse, it is surprisingly silent on how these institutions can be built or changed (but see Haslam, 2016; Orihuela, 2013, 2018; Dietsche, 2007). As Haslam (2016, p. 1146) states, the resource curse theory is "principally a theory of decline and has paid relatively little attention to how countries may turn back from the rentier to the developmental state". The principal policy implication of the literature is almost tantamount to a conviction: If states have good institutions, they will be able to turn their "rents into riches" (Barma et al., 2012). If not, they will succumb to the curse (Menaldo, 2016).

What the resource curse perspective has failed to consider is that institutional change under conditions of resource dependence is occurring, as discussed earlier for the latest commodity boom in the Andean region. In fact, if the curse is a function of the behavior of decision-makers, it cannot be excluded a priori that they can make good choices, even under potentially bad conditions (Dietsche, 2007; see also Grindle, 2004). Once the possibility of agency is granted, the important question is under which conditions decision-makers may decide to build institutions for good governance and under which conditions these may work towards mitigating or avoiding the curse and generating inclusive and sustainable development. Moreover, in the context of formal democratic rule and a globalized world, other actors may also be able to promote institutional change. Yet, given the resource curse theory's focus on the maladies and not the remedies, our understanding of how institutions emerge and function under the adverse conditions of poverty, inequality, limited state capacity, and resource dependence is still only preliminary. 


\section{Institutions and institutional change}

The subject of institutional emergence and change is treated primarily in an academic field referred to as institutional analysis, which is composed of three major schools: New Institutionalism Economics, Sociological Institutionalism, and Historical Institutionalism (Campbell, 2004; Hall \& Taylor, 1996). While these schools differ regarding their analytical foci and epistemological assumptions, institutions are generally understood, in the classical words of Douglass North (1990, p. 3), as the "rules of the game in a society. More formally, as the humanly devised constraints that shape human interaction". They consist of "formal and informal rules and the monitoring and sanctioning mechanisms that cause actors to comply with these rules" (Ibid.). As the definition indicates, institutions can be differentiated into formal and informal ones (Helmke \& Levitsky, 2006; Tsai, 2016; Fligstein, 1996). The former are understood in terms of written rules that are made, transmitted, and reproduced through channels widely thought to be official. In contrast, informal institutions represent "socially shared rules, usually unwritten, that are created, communicated and enforced outside of officially sanctioned channels" (Helmke \& Levitsky, 2004, p. 727). The legitimacy of these informal institutions is based on references to socially acceptable ways of doing things, claims to tradition, identity, rights, or existing or previous authority relations (Hall et al., 2014). Informal institutions exist everywhere, also in the context of formal organizations (such as state agencies, corporations, or social organizations). In some cases, actors may combine formal and informal institutional practices, developing hybrid institutional regimes (Sindzingre, 2006; Damonte, 2018, 2021).

Scholars across the different institutional schools understand institutions as products of specific power relations with - at least in the case of most economic and political institutions - significant distributional effects (Streeck \& Thelen, 2005b; Mahoney \& Thelen, 2010). Institutions are viewed as being sustained and imposed by those holding sufficient power to do so (Hall, 1986; Knight, 1992; Mahoney, 2010; Acemoglu \& Robinson, 2006). A similar perspective is offered by the political settlement approach within development studies, which focuses on how the informal constellation of power in any given polity affects the opportunities for institutional change (Khan, 2018; Di John \& Putzel, 2009). Conceiving of institutions as results of power relations has implications for their lifespan: They persist as long as those in power approve of them or are able to sustain them.

Treating power as a constitutive element of institutional emergence implies no judgment about their quality: they still can be good or bad. To grasp the effects of institutions on collective well-being, Acemoglu and Robinson (2012) differentiate between extractive and inclusive political and economic institutions. Extractive institutions are rules that allow a small group of individuals to exploit the resources (including human resources) of the polity in which they are acting. They can be found in many former colonies (Ibid.). Inclusive institutions allow for a wide participation of different social groups and individuals in the 
process of governing, attenuating, or preventing the exploitation of resources or people (or, for that matter, the resource curse). In a similar manner, the aforementioned settlement approach distinguishes between inclusive settlements willing to widely distribute development benefits and exclusive settlements where only elites capture the benefits (rents, money from donor corporation, etc.; see also Moore, 2004).

The literature discusses two pathways of institutional change: revolutionary or sudden change versus evolutionary or incremental change. The first presupposes a punctuated equilibrium model, in which large phases of institutional stability (thought of as an equilibrium) sustained by a specific coalition give way to comparatively shorter phases of sudden change (Mahoney, 2000). Such change happens in the context of critical junctures, understood as periods of contingency during which the usual constraints on action are lifted or eased. As a consequence, old institutions can be unmade and new ones emerge (Capoccia \& Kelemen, 2007).

Institutional change can also be endogenous, slow and, often not so visible (Mahoney \& Thelen, 2010; Streeck \& Thelen, 2005a; Campbell, 2004). It has been argued that the very nature of institutions as products of power relations renders them prone to slow and gradual change from within, not just during extraordinary critical junctures. For instance, coalitions sustaining specific institutions may change their interest due to developments in the external context and, consequently, change the rules. Also, ruling coalitions are often composed of different groups with heterogeneous goals (Palier, 2005; Schickler, 2001). Changes in the balance of power within these groups may lead to institutional change. In addition, institutions are generally open to ambiguity and interpretation (Sheingate, 2010; Thelen, 2004). One and the same rule may be interpreted and enforced in very different ways depending on the interests and resources of the sustaining coalition or the organization in charge of enforcement. Finally, compliance with institutions is itself always variable. In principle, all institutions can be politically contested or driven to exhaustion by non-compliance or gradual defection.

While in some instances institutional change can be driven by competition (Campbell, 2010), institutional models may also diffuse and reproduce from one organizational setting to another (DiMaggio \& Powell, 1983; Hannan \& Freeman, 1989). Referred to as institutional isomorphism, this latter mechanism takes place not only on the national level but also globally. Isomorphism can take the form of mimicry (when one party imitates institutions seen in other places that are perceived as attractive). Particularly in cases of global norm diffusion, coercion (when one party is able to force the other party to accept change) or norm-abidance (when different parties across the globe abide by international conventions and their institutional consequences) are driving forces. Indeed, many lower- and middle-income countries have adopted institutional reforms in response to pressures (or incentives) set by international organizations (e.g. World Bank, International Monetary Fund, or OECD; see Dobbin et al., 2007) or by complying with international conventions (such as UN conventions, see 
later). The theory of change implied is that these powerful international actors are able to set economic or status incentives which can pressure national elites or governments into institutional change. Furthermore, not responding to such international pressure could also generate undesired domestic situations such as social protests or electoral losses, which can motivate institutional change.

While gradual change is promoted by power holders or enforcers (political and administrative), the idea of sudden institutional change within critical junctures recognizes that actors outside of ruling coalitions may challenge the institutional status quo. As a matter of fact, especially in countries characterized by closed political systems, weak state structures, and large power asymmetries, pressures by non-elite challengers on those in power may be essential for changing the balance of power sustaining specific institutions or institutional arrangements (Lipsky, 1968; Piven \& Cloward, 1979). In this line, the Advocacy Coalition Framework (ACF) focuses on how policy change is produced in interactions among different advocacy coalitions (Sabatier \& Weible, 2007). Policies understood as the formal or informal guidelines for decision-making are not necessarily the same as institutions. However, the two may overlap when policies stipulate rules for specific actors and are enforced or publicly or by means of social pressure (Streeck \& Thelen, 2005b). Advocacy coalitions include generally a wide spectrum of different private and public actors, form on the basis of shared beliefs, and are characterized by a non-trivial degree of coordinated activity over time. Connecting to institutional analysis, it has been argued that coalitions are most likely to achieve policy change during critical junctures when the distribution of resources (money, public opinion, information, leadership, etc.) shifts so that coalitions are empowered to impose their demands for change (Sabatier \& Weible, 2007).

Policy or institutional change may also be promoted outside of established formal channels, in the streets, by means of social mobilization. For such a contentious challenge to emerge, political entrepreneurs have to accumulate resources, mobilize people with convincing interpretative frames, and seize on opportunities when they open up (Tilly \& Tarrow, 2007). Political outcomes caused by such mobilized actors vary from agenda setting to actual institutional reform (Kolb, 2007). Regarding the latter, research has stressed that mobilizers must win allies from within the system (Andrews, 2001) or else force decisionmakers into change. In this way, massive social mobilizations may create the critical junctures during which institutional change becomes possible (Kurzman, 1996).

Social activism to promote institutional or policy change is not limited to national boundaries. Globalization has set the conditions for transnational activism in which groups or individuals from different countries join to promote a common cause on a global level (Olesen, 2010; Tarrow, 2005; Della Porta \& Tarrow, 2004). These transnational movements or advocacy coalitions may address governments, international organizations, or private actors such as companies. Often, international conventions are promoted by international organizations and transnational advocacy groups alike. Transnational activism and advocacy 
matter for domestic institutional change as they provide material resources, knowledge and information, legitimacy, and network contacts to domestic challengers (Keck \& Sikkink, 1998). They may also trigger a boomerang-effect by convincing a powerful outsider (another government or an international organization) to pressure governments to give in to domestic demands (Ibid.).

\section{Institutional change in the Andean resource economies}

As explained in the previous section, institutional emergence and change can be gradual through different mechanisms or sudden in the context of critical junctures. Different actors may promote institutional change who can be classified according to two dimensions: the political level where they operate (domestic - international/global) and according to their power position, i.e. if they form part of the ruling coalition or if they are powerful international organizations or if they are external challengers to the institutional status quo. This classification can be translated into a matrix (Figure 2.1a) that differentiates into four types of agents of institutional change: domestic power holders/ ruling coalitions, domestic challengers, global powerful organizations, and transnational challengers.

These four types must be understood as ideal-types. In real life, it is often precisely the interaction of these actors that ultimately produces (or hinders) institutional change. In the following, we use this matrix as an organization principle for the review of research on dynamics of institutional change (including the chapters of this book) in the Andean resource economies. We focus on inclusive institutions intended to mitigate or avoid the different manifestations of the resource curse both during the latest resource boom as well as during previous episodes. The review is not meant to be exhaustive, but it aims at providing an overview of what empirical research has found so far.

Table 1.1 Four agents of institutional change

\begin{tabular}{|c|c|c|c|}
\hline & & \multicolumn{2}{|l|}{ Level } \\
\hline & & Domestic & International/global \\
\hline \multirow{8}{*}{ 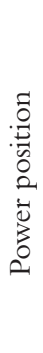 } & Powerholders & local and national & \multirow{8}{*}{$\begin{array}{l}\text { international } \\
\text { organizations; bi- } \\
\text { and multinational } \\
\text { donor cooperation, } \\
\text { transnational } \\
\text { corporations } \\
\text { transnational } \\
\text { advocacy networks; } \\
\text { transnational activism }\end{array}$} \\
\hline & & governments and elite & \\
\hline & & settlements/coalitions; & \\
\hline & & business actors & \\
\hline & & & \\
\hline & Challengers & social movements; & \\
\hline & & domestic advocacy & \\
\hline & & $\begin{array}{l}\text { coalitions; community } \\
\text { actors/activists }\end{array}$ & \\
\hline
\end{tabular}

Source: Own elaboration 


\section{Ruling coalitions as agents of institutional change: governments, elites, business}

Institutional change, promoted by domestic powerholders and ruling coalitions, may be the most obvious type since these agents hold the power to impose change. As mentioned earlier, these coalitions may integrate different groups with different power differentials, and institutional change may reflect a reconfiguration within an existing elite settlement. Historically, such new elite settlements or reconfigurations within these have profoundly shaped the governance of the extractive industries and the distribution of its rents (for the case of Bolivia and Peru, see Bebbington et al., 2018). Also during the latest commodity boom, governments have implemented institutional reforms to regulate the extractive sector and improve the distribution of its gains (rents) as well as its costs (particularly environmental costs). For instance, fiscal reforms have been implemented across the region to enhance the public share of rents produced by the natural resource sector (Jiménez, this volume). In many countries, the rents of the sector were decentralized, benefitting in the first place the producing regions (Jiménez, this volume; Arellano-Yanguas, 2011; Arellano-Yanguas \& Acosta, 2014). Likewise, innovative social policies such as conditional cash transfer programs fueled by the rents of the economic boom have been introduced all over the region (Evia, this volume; Osorio, 2020; Borges, 2018; Hunter, 2021). Governments have also adopted new environmental legislation to reduce the ecological damages caused by the extractive sector (Bornschlegl and Paredes \& Figueroa, this volume; see also Orihuela \& Paredes, 2017; Madariaga, 2018; Orihuela et al., 2021; Bravo, 2021; Orihuela \& Granados, 2021).

Diverse incentives that drove governors or ruling coalitions to adopt institutional change included domestic social pressure and conflicts (see later; Bebbington, 2012; Arellano-Yanguas, 2011; Humphreys Bebbington \& Bebbington, 2010) or the desire to prevent them (Arellano-Yanguas, 2011), the existence of high profits that motivated governments to capture a greater share of the rents and distribute them more widely (Haslam \& Heidrich, 2018), and ideological convictions (Ibid.; Kaup, 2010).

Policy diffusion took place through external coercion by international actors and by norm-abidance to international conventions (see later). Likewise, diffusion by mimicry has been identified as a driving force behind change. For instance, beginning in the early 2000s the already-mentioned conditional cash transfer programs diffused throughout the region because governments imitated the successful Brazilian example (Borges, 2018; Osorio, 2020). More generically and sustained by a mix of diffusion mechanisms, the diffusion of the green state in Latin America, i.e. the establishment of state institutions in charge of environmental protection, has been explored by Orihuela (2014). However, as the author makes clear, such processes of diffusion never suppose the establishment of global institutional blueprints. They are always subjected to processes of local adaption, which causes variation in their outcomes and effectiveness. 
Institutional change towards mitigating the resource curse has also been the result of mutual learning processes among elites. In Chile, learning processes among the national elites led to the establishment of Sovereign Wealth Funds that allowed for a more cautious macro-economic management of the Chilean resource economy (Orihuela, 2013). In fact, cooperation and learning among elites has always been a factor in taming the resource curse in Chile, at least in some of its expressions. Already in the 19th century, Chilean elites agreed to invest the rents from the resource sector into building a strong and capable state apparatus that formed the fundament for subsequent institutional change aiming at mitigating the curse (Kurtz, 2013).

Although not necessarily a direct part of the government or ruling coalition, business actors generally also command power. In fact, the resource curse literature attributes business a causal role in the production of the curse by profiting from rent-seeking activities and resisting change (Karl, 1997; Kaup, 2010; Durand, 2019). Business elites are without any doubt powerful political players in Latin America (Clark \& North, 2018). However, despite the assumptions of the resource curse literature, Haslam (2016) stresses the role of strong business actors in driving institutional change to tame the resource curse. Comparing Chile and Argentina, he found that in Chile a strong business community was able to pressure the state into a shift from a rent-seeking strategy to an entrepreneurial strategy. As a consequence, several expressions of the curse could be mitigated by promoting productive investments, joint ventures, and entrepreneurial learning. The author also shows that the support for institutional change was selective. In other cases, business remained passive vis-à-vis the rent-seeking activities of the state (e.g. within the Chilean National Mining Company ENAMI), which constrained institutional change in these sectors. In Argentina, quite to the contrary, weak business associations at the federal and provincial levels were unable to counter politicians' rent-seeking, thereby perpetuating the resource curse. A similar argument on the positive relationship between cohesive business networks and elites' willingness to support a fairer distribution of national resources is made by Cárdenas (2020). Saylor (2014), on the other hand, theorizes that the rents of the resource sector tend to be used in a productive way and to strengthen the state when exporter interests are represented in the respective ruling coalition (which he found to be the case in Chile and Argentina).

Last but not least, during the latest boom period in the Andes, companies have gradually intensified their community relations with the communities living near their projects, mostly in order to prevent or mitigate social resistance (Frederiksen, 2018). Scholars have begun to analyze these new practices and rules introduced by companies in the localities where they operate as part of their Corporate Social Responsibility (CSR) programs (Himley, 2012; Leiva, 2019; Haslam, 2021; Bebbington, 2010). They have focused on the consequences of these programs in terms of local development, social cohesion, and state-society relations. The findings of these studies are mixed: While some practices such as providing housing or public infrastructure or producing social 
capital may qualify as inclusive and able to counter the (local) curse (Cesar \& Jhony, 2020), others have been found to exacerbate local inequalities, legitimate ecological destruction, and promote tensions among community members (Gamu \& Dauvergne, 2018).

\section{International actors as agents of institutional change}

Powerful international actors, in particular bi- and multilateral donor cooperation, have also promoted institutional change in the Andean resource economies. Using different leverages, particularly financial ones and the assignment of symbolic capital for internationally approved good behavior (Larsen, 2016), international agents have achieved a lasting impact on the institutional arrangements capable of mitigating the resource curse in the Andean countries.

The influence of multilateral actors comprises a wide array of sectors and institutions. For instance, the United Nations have shaped many domestic environmental systems in the region on the basis of the UN Rio Convention adopted in 1992 during the Earth Summit in Rio de Janeiro (see Godfrid for Argentina and Rabi and Campos for Chile, this volume). Also, the UN declarations of Human Rights and Indigenous Rights were translated into the domestic law of several Andean countries. Likewise, the European Union has shaped institutional developments in the region, promoting amongst others environmental and labor regulation, especially as part of their free trade agreements (for instance with Colombia, Peru, and Chile).

International organizations such as the World Bank and the IMF ever since had an enormous impact on economic and fiscal reforms in the region, starting with the austerity measures applied in the 1980s. While in the past often criticized for promoting extractive institutions, during the recent boom period these organizations have also promoted institutional change with the potential to mitigate the resource curse, as several chapters in this volume show. For example, the World Bank conditioned a considerable credit to bolster the mining sector to the establishment of an environmental ministry in Peru (Paredes and Figueroa, this volume; Orihuela \& Paredes, 2017). Chile and Colombia (as actual members) and Peru (as an aspiring member) have set up new regulatory institutions in order to meet the membership requirements of the OECD. In Chile, the OECD required a public environmental system as a condition for the country to obtain full OECD membership (Maillet and Carrasco and Rabi and Campos, this volume). Also, several specific regulations, such as the carbon tax and measures against air pollution, were a direct result of OECD recommendations (Madariaga, 2018). Previous to that, anti-corruption and transparency legislation was adopted to fulfil OECD requirements. Peru and Colombia have to different degrees responded to OECD requirements: Colombia introduced major reforms in the labor sector and justice system, as well as regarding transparency and anti-corruption. Similarly, Peru has translated OECD standards regarding transparency in the public administration, anti-corruption, and environmental standards. As an example of the influence of a single bilateral 
donor, Godfrid (this volume) shows that in the Argentinian province of San Juan, Japanese cooperation was deeply involved in the establishment of new environmental rules.

Regarding transparency in the extractive sector, the transnational EITI framework has made some inroads in the region (Bebbington et al., 2016). As an initiative bringing together corporate, civil, and governmental actors, the Extractive Industries Transparency Initiative (EITI) was launched in 2007 on initiative of former British Prime Minister Tony Blair to promote standards for transparency and accountability in the management of revenues from natural resources. Countries commit to the EITI standard on a voluntary basis and become full members only following an independent certification of accounts that reconcile the figures that companies report having paid and government says it has received. Peru and Colombia are full EITI members and have adapted to the organizational standards. Ecuador and Argentina have solicited membership and are being evaluated against the EITI standards.

Often, several international actors have promoted the same institutions in the region. For instance, political and fiscal decentralization was a core subject of bi- and multilateral donors' influence during the 1990s and early 2000s (OECD, 2004). The diffusion of the green state as studied by Orihuela (2013) has been supported by different international actors. Several important concepts applied in the regulation of natural resources were promoted by bi- and multilateral donor cooperation. To name just a view out of many: The concept of Integrated Water Resources Management was promoted as particularly important for regions affected by mineral extraction and has been adopted in several national water sectors in the Andean region (Biswas et al., 2009). Concepts for land use planning aiming at the sustainable use of natural resources have been diffused by international organizations and NGOs throughout the region (Gustafsson et al., 2020). Finally, during years of new formats of citizen participation - in general to enhance the legitimacy and transparency of political decisions (Peruzzotti, 2012; McNulty, 2012; Leal, 2007) and in particular to improve resource governance and environment protection-have ranked high on the international agendas for the Andean countries and were introduced as new domestic rules in several target countries (Paredes \& Schorr, 2021).

\section{Domestic and transnational challengers as agents of change}

Domestic and transnational challengers promoting institutional change from the outside of the political establishment can take the form of advocacy coalitions or social movements and protest groups. During the last decade, academic interest in the dynamics of social conflicts motivated by extractive projects and politics has grown exponentially, although with a minor focus on the outcomes and legacies of these conflicts. In the first place, activism has been found to achieve the suspension of projects or to impose significant changes to their original design (Delamaza et al., 2017 for the case of Chile). In a few cases, researchers showed that social conflicts provoked institutional changes (Bebbington, 2012): 
In Peru (Arellano-Yanguas, 2011) and in Bolivia (Humphreys Bebbington \& Bebbington, 2010), social contention led to new laws regarding the distribution of revenues stemming from mining and hydrocarbons. Protest reclaimed new forms of citizen participation (for the case of Peru, see Paredes \& Schorr, 2021), including the legal regulation of consultation processes with indigenous communities (Flemmer, this volume). In Ecuador, social pressure managed to shape the new mining legislation that introduced inter alia the concept of no-go zones in forest reserves and near rivers (Moore \& Velásquez, 2011). In 2021, a popular referendum growing out of years of social activism vetoed mining activities in the Ecuadorian province of Azuay, one of Ecuador's new mining hotspots (Wingfield et al., 2021). The conflict in the Argentinean region of Esquel spurred seven out of 23 provinces to ratify a mining ban prohibiting open-pit mining activities in their territories (Walter \& Martinez-Alier, 2010). Furthermore, the adoption/refinement of a new environmental regulation in San Juan, Argentina can be attributed partly to social protests (Godfrid, this volume). In Chile and in Peru, advocacy coalitions managed to pressure legislators to adopt new regulations for political transparency (Schorr, this volume) and imposed environmental regulation with regard to the mining sector in the Ecuadorian Intag valley (Flora et al., 2006) and in Chile (Madariaga \& Allain, 2018).

As mentioned previously, institutions can be differentiated into formal and informal ones. Agents external to ruling coalitions have also influenced the establishment of informal institutions, both as organized and non-organized actors. For instance, mobilized groups introduced new forms of informal political institutions such as the popular referendums conducted in Argentina, Peru, and Colombia (Dietz, 2019; Walter \& Urkidi, 2017). Moreno (this volume) establishes a connection between the increasing perception of political corruption during the post-boom phase and the ways citizens in the Andean countries view democracy and participate in politics. He finds that the significantly increased perception of corruption correlates strongly with informal ways of engaging in politics, such as street mobilizations and activism in neighborhood associations. In contrast, formal participation, for instance in elections, is declining throughout the region, as is trust in democracy in general. Finally, locallevel actors can also achieve institutional change regarding the ways resources are governed, in case they are strong enough to negotiate with the state for the recognition of local informal rules. This can be observed in the informal mining sectors in Bolivia, where the mining cooperatives were important allies of the Morales government (Amengual \& Dargent, 2020), and in Peru, where informal miners mustered sufficient political strength (by means of social mobilizations as well as by forming coalitions) to prevent the state from imposing its institutional agenda in local resource governance (Damonte, 2018, this volume).

Traditionally, transnational advocacy has played a significant role in promoting environmental standards and human rights in Latin America (Keck \& Sikkink, 1998). Generally, the role of transnational advocacy is supportive, and, in fact, several of the domestic challenges mentioned earlier have benefitted from transnational advocacy. Flemmer (this volume), for instance, stresses the role of 
transnational advocacy in the promotion of prior consultation in particular and indigenous rights in general. During the latest boom, transnational advocacy was more involved in particular campaigns against certain projects or corporations. For instance, the social conflicts over the mining projects in Pascua Lama in Chile (Schorr, 2018; Urkidi, 2010), Tambogrande (Haarstad \& Fløysand, 2007) and Espinar (Paredes, 2016) in Peru, and Cotacachi in Ecuador (Kuecker, 2007) have involved global advocacy groups bringing together diverse national and global watchdog groups, NGOs, and international organizations to support local actors in their struggles against extractive projects promoted by states and corporations.

\section{From institutional adoption to institutional performance}

As laid out previously, institutional change promoted by different actors has been widespread in the Andean region during the latest boom period and before. However, as a large political science literature reminds us, the adoption of new rules does not automatically translate into the intended behavioral change (Pressman \& Wildavsky, 1984; Sabatier, 2005; Mazmanian \& Sabatier, 1983). It has been stated that particularly in Latin America the adoption of new or the transformation of existing formal rules is rather frequent (Brinks et al., $2019,2020)$. The problem is that for several reasons these institutions remain ineffective, which would translate in our case into them losing their potential to mitigate the resource curse. In this section, we discuss a series of factors that research has found to constrain the effectiveness of institutions. Our aim is to give an overview over those forces and dynamics critical for scholarly assessment of the performance of institutions intended to tame the curse in resourcedependent contexts, using examples from this volume.

One of the main causes constraining institutions' potential effect is the lack of political will to enforce effectively, which can reduce institutional change to an act of window dressing by governments (Ibid.). The literature argues that governments create such window dressing institutions as an answer to external pressures (social protests or international organizations) to demonstrate commitment, while de facto they have no intention to implement them. In some cases, lobbyism by business elites may further reduce the political will to enforce or contribute to keep it low (Durand, 2016).

Non-enforcement can be achieved in different ways. Governments may choose to simply ignore a rule while leaving it on the books. More sophistically, non-enforcement can be ensured by shaping enforcement agencies in a way that they are unable to implement the rules of the institution of which they are officially in charge. This can include denying the allocation of sufficient resources, professional staff, or authority necessary to act. Research on Latin America in general and the Andean region in particular has identified weak enforcers as a cause of institutional ineffectiveness in a wide array of cases, including new indigenous autonomies introduced in Bolivia (Tockman \& Cameron, 2014), utility regulation (Murillo, 2009), environmental institutions (Orihuela \& 
Paredes, 2017; Orihuela \& Granados, 2021; Orihuela et al., 2021), and political decentralization (Dickovick \& Eaton, 2013). In fact, in postulating politicians' tendency to rent-seeking and political myopia, the resource curse literature would lead us to expect that in cases where agents managed to impose regulatory institutions against the adverse dynamics triggered by resource dependence, the political will to enforce them effectively would be thin. This should be particularly true for those institutional changes promoted by international agents or by social pressure, a point indeed made by various chapters in this book (see the chapters by Flemmer, Godfrid, Paredes and Figueroa, Maillet and Carrasco).

On the other hand, states may enforce selectively following different logics, a phenomenon which has been shown to be particularly pronounced in unequal societies such as the Andean ones certainly are (Amengual \& Dargent, 2020). States may bring the rule of law to bear on poor people while desisting from enforcement in wealthier segments (Brinks, 2008; Méndez et al., 1999), they may ramp up enforcement in some regions and not in others (O'Donnell, 1993; Soifer, 2015), or they may enforce rules against political enemies while being forbearing with political allies or electoral constituencies (Holland, 2017). The latter has been found in the case of enforcement of different types of regulation in the small-scale mining sector in Bolivia: Given that the mining cooperatives were close allies of the Morales government, regulation was not enforced against them (Amengual \& Dargent, 2020). Likewise, companies have been shown to avoid the rigid enforcement of regulatory legislation in the environmental sector or regarding the transparency of their financial transactions because of their close relations with governments and politicians (Bull \& Aguilar-Støen, 2016).

The lack of effective implementation is not always a direct reflection of a lack of political will. Non-enforcement or selective enforcement may result from an actual lack of resources. This factor is of particular importance for resource economies. Given the inherent volatility of the global markets, resource economies tend to alternate between phases of growth (booms) and phases of bust in which the rents of the resource sector diminish. In times of decreasing global demand, public accounts shrink and with them the ability of states to enforce. In the Andes, the most recent bust cycle has led to a significant reduction in public budgets. As a consequence, public investments including social spending have dropped significantly (Jiménez and Evia, this volume). A particular harsh example for this dynamic is Bolivia, where social programs are directly tied to the existence of resource rents. The lack of resources provoked by the economic downturn has also affected enforcement in the environmental sector, as Bornschlegl and Godfrid (this volume) show for the cases of Ecuador and Argentina respectively.

Even if political will exists and a stable access to resources is guaranteed, effective implementation of institutions may still be hampered by a lack of professional capacity and the absence of skilled enforcers (Peters, 2018). In addition, organizations are not only a mere consequence of the institutions they are supposed to enforce; they also lead a life of their own (Dargent, Orihuela et al., 2017, p. 14). The management and administrative staff have a certain 
autonomy over the rules they are in charge of, which can affect the way implementation is carried out and hence the effectiveness of institutions (Mahoney \& Thelen, 2010). In Latin America in general and in the Andean countries in particular, bureaucratic capacity is low, which reduces the degree and quality of implementation (Polga-Hecimovich, 2019). This has also been shown for institutions capable of mitigating the resource curse. For instance, Orihuela et al. (2021) attribute the lack of enforcement in the Peruvian environmental sector to the absence of a professional bureaucracy. Likewise, Paredes and Figueroa (this volume) call attention to the fact that the lack of skilled and motivated staff is limiting the operation of the new Peruvian Environmental Ministry. They argue that notwithstanding formal institutional change, the actual practices of bureaucrats within the new organization have not changed. For this reason, the regulatory capacity of the ministry and its executive organs remains weak.

Another factor potentially reducing the effectiveness of institutions is their design. Design can, on purpose, produce insignificance and establish window dressing institutions (Brinks et al., 2020). In this volume, Rabi and Campos argue that the Environmental Courts in Chile correspond to such a pre-emptive design. They argue that the courts have been set up intentionally in a way that would not put too many constraints on the extractive sector. Maillet and Carrasco (this volume) state the same for the whole Chilean environmental system, to which the courts studied by Rabi and Campos belong. They argue that the Chilean environmental subsector is nested in a powerful extractivist economic system and too weak to actually constrain it effectively. As a consequence, both the number of the projects as well as the conflicts surrounding them have increased. Also, Paredes and Figueroa (this volume) mention the relative powerlessness of the Peruvian environmental ministry vis-à-vis the powerful economic ministry MEM. The institution of prior consultation of indigenous peoples can also be interpreted as flawed by design. It is non-binding, neither actor must stick to the agreements, monitoring mechanisms are absent, and communities do not have the possibility to reject the realization of the project in their territory (Flemmer, this volume; see also Torres Wong, 2018; SchillingVacaflor \& Flemmer, 2015; Falleti \& Riofrancos, 2018). Thus, the effects that prior consultation actually produces are insignificant or outright counterproductive because they often increase social conflict, both within communities as well as between communities, corporations, and the state (Schilling-Vacaflor \& Eichler, 2017).

As with ineffective enforcement, default by design is not always the product of a strategic political calculus. Specific design features may generate unanticipated effects that may distort the actual objective of an institution when it operates. Such unintended effects can be observed in the fiscal reforms implemented during the latest resource boom in the Andes. While holding the potential of a more equal distribution of the extractive sectors' rents, in almost all countries of the region the reformed fiscal systems have produced or reinforced territorial inequalities (Jiménez, this volume). Unintended effects may be particularly prominent in case of global norm diffusion, when governments 
import institutional models developed and applied in other contexts. This has been studied by Weyland (2006) who showed that neighboring governments borrowed the model of private contribution-based pension system implemented in Chile because they perceived it as successful. However, these utterly failed under the entirely different conditions of Bolivia and Peru. Imported institutions may also fail to generate social commitment, as Paredes and Figueroa (this volume) claim for the case of the Peruvian environmental agency OEFA. Because this agency was perceived as alien by local actors, it ended up being unable to articulate political or social support to defend the rules it is supposed to enforce.

Finally, the chances for effective implementation also depend on how-by design-infraction is charged. If sanctions are so minimal that they do not cause deterrence, actors may be willing to accept the costs the sanctions imply which ends up hollowing the effect of the institution (Brinks et al., 2020). Such nonpunitive sanctions are applied to supposedly halter deforestation in Argentina (Fernández \& Garay, 2020, Amengual \& Dargent, 2020). They also can be found in the case of the Peruvian mining sector, where fees for environmental misconduct are so low that companies tend to pay them instead of changing their behavior and protecting the environment. Likewise, companies in the Ecuadorian oil sector prefer to pay administrative fines instead of maintaining their pipelines and avoiding oil spillings (Bornschlegl, this volume).

The effective implementation of institutions does not only depend on state capacity and the political will to enforce them. It is also a function of the willingness of citizens to accept and comply with institutions (Amengual \& Dargent, 2020). As stated before, states may lack the resources and capacity to enforce. In the Andean countries even, their territorial outreach is constrained. In many parts of the vast territories in the Amazon lowlands and the Andean highlands, the state is not present at all and other actors impose social order (e.g. indigenous communities or criminal groups).

In light of the role of such powerful non-state actors, it has been argued that state capacity has to be understood as relational (Dargent, Feldmann et al., 2017). States may be too weak to enforce specific institutions against the will of strong social groups or populations. In this volume, Damonte analyzes how both informal miners in the Peruvian Amazon as well as agroexporters in the region of Ica have managed to resist the institutional agendas of the central state and imposed their own informal practices in the sectoral governance.

Resisting the implementation of state institutions may be reinforced by a lack of trust in the state or its enforcers. Social acceptability of an institution is highly dependent on citizens' trust in public institutions and the state in general. The opposite, mistrust in the state and its enforcers, impedes the effective enforcement of institutions. It can be assumed that this factor has a particular weight in the Andean countries, where social trust in the state ranges among the lowest in the region (Moreno, this volume). Confirming this point, Bornschlegl finds in her case study, on the implementation of the program of environmental reparation in the Ecuadorian Amazonas, that local peoples' mistrust in the state 
and in the programs' officials significantly complicated the implementation of the new environmental institutions.

\section{Organization of the book}

This book is concerned with institutional change that could mitigate or avoid the different expressions of the resource curse in the context of resource dependence, poverty, and weak state capacities. We understand institutions as those formal and informal rules structuring human behavior and the monitoring and sanctioning mechanisms that cause actors to comply with these rules. Institutional change refers to the emergence of new rules or the qualitative transformation of existing ones so that their effect is enhanced.

Empirically, we focus on institutional developments in the Andean countries during the latest resource boom and the first post-boom years (2004-2014). Economically, these countries rely heavily on their extractive sectors, while state capacity in the region tends to be low (with the exception of Chile; see Soifer, 2015) and poverty, as well as social inequality, is high.

The chapters of this book focus on inclusive regulatory institutions in those governance sectors where the resource curse can unfold. They identify the agents and forces driving institutional change and explore the performance of these new institutions. In particular, the chapters study redistributive institutions, rules that ensure political transparency, participation and democratic governance in general, and environmental protection rules. We move beyond the economic institutions in our discussion because these have long been the focus of resource curse scholarship.

The book pursues two objectives: First, it delivers sound empirical evidence on institutional change and performance in the Andean countries before and during the latest boom period as well as the first post-boom years. Since the chapters are written from different disciplinary perspectives, they provide an abundant panorama of cases and approaches by using different qualitative and quantitative methods. Extending the period under analysis into the post-boom years further allows us to explore whether economic cycles affect the dynamics of institutional change and performance.

Second, the volume contributes to the theoretical development of the widely discussed resource curse approach by adding insights into the conditions that support or hinder institutional development in settings potentially affected by the curse. The chapters discuss different factors promoting change and affecting institutional performance. Moreover, in the concluding section, we elaborate an interdisciplinary research agenda on institutional change in resource-dependent contexts. This agenda is based on the analytical insights provided by the different chapters and binds them together in order to orient future research on the subject.

The book is organized into three sections: After this introduction, the second section contains 12 empirical studies that explore institutional change and performance in different Andean countries. We summarize each of these chapters briefly. 
The second section is opened by Jiménez's analysis of the fiscal reforms introduced in several Andean countries during the latest boom period. In particular, he examines the impact these reforms had on the public accounts, on the fiscal space, and on regional inequality. The chapter reveals that significant reforms have been undertaken in almost all countries of the region. As one effect, public accounts registered important increases that, amongst others, allowed for the implementation of new redistributive policies. However, the author also identifies two shortcomings of these reforms: First, fiscal resources stemming from the natural resource sector depend on the extreme volatility of the global markets. Once the boom period had receded, the sector's rents decreased dramatically, and with them the public accounts. Second, the new spending rules reinforced territorial inequalities in a region already hit by some of the highest regional disparities in the world.

Focusing on Bolivia as a single case study, Evia explores the social policy innovations adopted between 2003-2014. He states that these innovations were possible due to the reorganization of the hydrocarbons sector in the 1990s that paved the way for the unprecedented influx of rents during the latest economic boom period. These rents then allowed the government of Evo Morales to set up a social protection floor based on a series of conditional cash transfer (CCT) programs, an institutional model that had diffused throughout the region motivated by the Brazilian example. These new CCT are widely considered to have contributed to the impressive reduction of poverty experienced in Bolivia during the last decade. However, Evia also finds that these new institutions are financially unsustainable: Since the CCT were designed to depend directly on the influx of rents and hence on global demand, the economic downturn of the post-boom has led to important adjustments in volume and coverage. As Jiménez before, the author shows that institutional change towards inclusive institutions was possible but flawed by design.

The next chapter by Cisneros observes institutional dynamics within the wider extractivist sector in Ecuador. Against the prediction of the extractivist imperative debate, which holds that the extractive sector, once established, will continuously expand, Cisneros shows that in Ecuador the political intention to establish a mining industry along the lines of the traditional oil sector has failed. While some authors point to social resistance as the driver behind this failure, Cisneros offers another explanation. He argues that social protest was an important force for keeping mining at bay, but equally important for the expansion of the sector to fail were the institutional path dependencies created by the long tradition of oil extraction in Ecuador. These ultimately prevented, what the author calls, an extractive diversification in Ecuador.

Damonte calls attention to dynamics of institution-building in extractivist countries on the subnational level. He explores two cases of institutional emergence within the governing regulation of the Peruvian extractive sector: water extraction in Ica, mostly by large companies, and gold mining in Madre de Dios, mostly by informal small-scale miners. The author finds that locally a hybrid governance model was established that combines informal with formal 
institutions. The cases show that institution-building initiated by the state in order to govern extractive activities in territories of weak state control is a function of the agency and political leverage of the state but also of other social actors involved.

Flemmer studies the introduction of the framework for prior consultation of indigenous people, as stipulated in the ILO Convention No. 169, as a means of reducing the social and environmental impacts of extractive projects. The chapter explains the adoption of this framework by all Andean countries as a case of global norm diffusion promoted by international organizations and transnational advocacy. Drawing on the case of Peru, Flemmer analyzes the implementation of prior consultation and identifies a series of pitfalls, amongst which the limitations of the legal texts and processes imposed by the state in cooperation with corporate actors are the most important ones. As in the case of social and fiscal policies, the Peruvian law of prior consultation is flawed by design. Contrarily to the case of social and fiscal policies studied by Jiménez and Evia, Flemmer argues that the framework was intentionally downsized to avoid indigenous communities having a real say over the realization of extractive projects in their territories.

Using public opinion data for several Andean countries, Moreno traces in his chapter the evolution of the perception of corruption and explores the effects of citizens' perception of corruption on the quality of democracy. The author finds that the perception of corruption increased sharply as resources started to run short, i.e. when the boom subsided. In line with the resource curse literature, he confirms with statistical data that the perception of corruption indeed seems to have a detrimental effect on the support for democracy, affecting both trust in elections and satisfaction with how the political system is working in the country. Likewise, individual experience with corruption in the Andean countries shapes new informal institutions by increasing the chances that a person participates in extra-institutional political activities, such as street manifestations, and autonomous community-based activities. Like Damonte, Moreno calls attention to the effects that dynamics related to the resource sector can have on local informal practices.

In the next chapter, Schorr explores the contentious political processes to impose more effective political transparency rules in Chile and Peru. She argues that in both countries the same mechanism of change was at play, involving a combination of pressure from the inside of governmental institutions as well as from the outside: A strategic coalition among presidents and civil society actors was able to build circumstances in which delegates could not afford to vote against the reform proposals. However, the comparison between the political processes in Chile and Peru also leads the author to qualify the institutions matter argument of the resource curse literature. The analysis identifies the importance of the quality of the institutional fundament in place. In other words, resource economies can only be governed in a good way when the very political fundament of the polity in question - the grounds on which those institutions that matter have to be negotiated-is of a good quality. 


\section{Bettina Schorr and Gerardo Damonte}

Maillet and Carrasco analyze Chile's environmental system, which was established in response to requirements formulated by the OECD as a condition to obtain full membership. Chile's environmental system thus constitutes a type of global isomorphism and an example of the diffusion of the green state in the region. The authors argue that the environmental legislation adopted in 2010 is only apparent change. Factually, it does little to prevent environmental damage caused by the extractive industries because the institutional changes in the environmental subsystem are nested in a largely unchanged extractive regime. As a consequence, the overall regulatory impact of the new environmental institutions is low as documented in the increase of investments in the extractive sector as well as the growth of social conflicts around extractive projects.

The next chapter by Rabi and Campos connects to the previous chapter by exploring in detail the Environmental Courts (EC) in Chile established in 2012 as part of the new environmental system. The authors argue that policy-makers designed the EC with very limited authority in order to prevent them from inhibiting the activities of the extractive sector. Institutional barriers include the exclusion of individuals as claimants and limiting its authority to revising decisions issued by other state institutions. Moreover, analyzing the cases, claimants, and judgments the courts had issued until 2017, the chapter finds that environmental courts are used mainly by companies who contest decisions made by other state agencies against their projects, such as sanctions imposed by the Superintendence of the Environment. In contrast, communities not only are underrepresented as claimants, but also lose their cases in a greater proportion than the companies running the projects. The analysis of the actual operation of the EC, thus, shows that not only design matters and the behavior of officials, but also how social actors make use of institutions.

Paredes and Figueroa discuss the establishment of the Environmental Ministry in Peru. As the environmental framework in Chile, this new public institution was established in a top-down fashion based on international models promoted by the World Bank. It constitutes thus a case of institutional isomorphism. Moreover, the World Bank pressured the Peruvian governments to adopt the new institution by tying it to a considerable credit. Specifically, Paredes and Figueroa argue that the new environmental institution was imposed without dismantling old and ineffective institutional practices and established identities related to the bureaucratic culture in Peru. Thus, despite the new formal institutional setup, actual bureaucratic operating practices did not change, which significantly weakened the regulatory capacities of the new institution from the very beginning. Furthermore, perceived as something alien and imposed from external actors, the new environmental agency was unable to articulate political or social support to defend the new rules.

Bornschlegl examines the institutionalization of the concept of integral reparations, included in 2008 in the new Ecuadorian constitution, and institutionalized as a proper state program: the program of Social and Environmental Reparation (PRAS) at the Ecuadorian Ministry of Environment. The author identifies the most critical constraints it encountered. She finds that the enforcement of 
the reparación integral was severely constrained by three lacking elements: a lack of funding, a lack of executive power, and a lack of trust on part of the local communities. As a consequence of these shortcomings, the new legislation was unable to reach its stated aims.

Godfrid addresses changes to the environmental monitoring institutions for the mining sector in the province of San Juan, Argentina during the period 1993 to 2020. She argues that the main factors that have motivated the institutional transformation of environmental monitoring of mining were coercion by international agencies (1993-2002), socio-environmental conflicts (2003-2014), and mining accidents (2015-2019). These external factors prompted the creation of regulations and bureaucratic departments for the environmental oversight of mining that did not previously exist at the subnational level. However, the political decision by the authorities in San Juan to prioritize mining led to a reactive institutional change that limited the capacity for environmental oversight as well as the means to respond to public demands for transparency and participation. The analysis shows that the political dimension is key to understanding the reactive institutional change process and in particular the weakness of the environmental oversight institutions for mining in San Juan.

The book closes with the third section that contains the concluding chapter. In this conclusion, we summarize the main contributions of the volume and sketch a research agenda for future investigations into institutional dynamics in contexts characterized by resource dependence and weak state capacities. As the book in general, this research agenda is thought of as a first step. We hope that it will contribute to advance research in the important questions the book is raising in order to enhance our knowledge on how actors may master adverse situations by building and implementing effective regulatory and inclusive institutions.

\section{References}

Acemoglu, D., \& Robinson, J. A. (2006). Economic origins of dictatorship and democracy. Cambridge University Press.

Acemoglu, D., \& Robinson, J. A. (2012). Why nations fail: The origins of power, prosperity, and poverty. Crown Business.

Amengual, M., \& Dargent, E. (2020). The social determinants of enforcement. In D. M. Brinks, S. Levitsky, \& M. V. Murillo (Eds.), The politics of institutional weakness in Latin America (pp. 161-182). Cambridge University Press. https://doi.org/10.1017/9781108776608.007 Amézquita Zárate, P. (2014). Minería y petróleo en Colombia: Maldición interna de los recursos. Económicas CUC, 35(1), 45-59. https://revistascientificas.cuc.edu.co/ economicascuc/article/view/217

Andersen, J. J., \& Aslaksen, S. (2013). Oil and political survival. Journal of Development Economics, 100(1), 89-106. https://doi.org/10.1016/j.jdeveco.2012.08.008

Andrade, S., \& Morales, J. (2007). The role of the natural resource curse in preventing development in politically unstable countries: Case studies of Angola and Bolivia. Development Research Working Paper Series No. 11. Institute for Advanced Development Studies. 
Andrews, K. T. (2001). Social movements and policy implementation: The Mississippi civil rights movement and the war on poverty, 1965 to 1971. American Sociological Review, 66(1), 71-95. https://doi.org/10.2307/2657394

Arellano-Yanguas, J. (2011). Aggravating the resource curse: Decentralization, mining and conflict in Peru. Journal of Development Studies, 47(4), 617-638. https://doi. org $/ 10.1080 / 00220381003706478$

Arellano-Yanguas, J., \& Acosta, A. M. (2014). Extractive industries, revenue allocation and local politics. UNRISD Working Paper No. 4. UNRISD. www.econstor.eu/bitstream/10419/148753/1/861317270.pdf

Auty, R. M. (1993). Sustaining development in mineral economies: The resource curse thesis. Routledge.

Barja Daza, G., \& Zavaleta Castellón, D. (2016). Disminución de precios de commodities en un ambiente de enfermedad holandesa y bendición/maldición de los recursos naturales. Revista Latinoamericana de Desarrollo Económico, 25, 7-40.

Barma, N. H., Kaiser, K., Le, T. M., \& Vinuela, L. (2012). Rents to riches? The political economy of natural resource-led development. World Bank. https://openknowledge.worldbank.org/ handle/10986/2381

Bebbington, A. (2010). Extractive industries and stunted states: Conflict, responsibility and institutional change in the Andes. In K. Ravi Raman \& R. D. Lipschutz (Eds.), Corporate social responsibility: Comparative critiques (pp. 97-115). Palgrave Macmillan.

Bebbington, A. (Ed.). (2012). Social conflict, economic development and extractive industries. Routledge.

Bebbington, A., Abdulai, A.-G., Bebbington, D. H., Hinfelaar, M., \& Sanborn, C. A. (2018). Governing extractive industries: Politics, histories, ideas. Oxford University Press.

Bebbington, A., Arond, E., \& Dammert, J. L. (2016). Scalar politics and transnational governance innovations: A political settlements lens on the extractive industries transparency initiative in the Andes. Global Development Institute Working Paper Series. The University of Manchester.

Bebbington, A., \& Bury, J. (2013). Subterranean struggles: New dynamics of mining, oil, and gas in Latin America. University of Texas Press.

Biswas, A. K., Braga, B. P., Tortajada, C., \& Palermo, M. (2009). Integrated water resources management in Latin America. Taylor and Francis. http://gbv.eblib.com/patron/FullRecord. aspx?p=1395763

Borges, F. A. (2018). Neoliberalism with a human face? Ideology and the diffusion of Latin America's conditional cash transfers. Comparative Politics, 50(2), 147-167. www.jstor.org/ stable/26532676

Boschini, A. D., Pettersson, J., \& Roine, J. (2007). Resource curse or not: A question of appropriability. Scandinavian Journal of Economics, 109(3), 593-617. https://doi. org/10.1111/j.1467-9442.2007.00509.x

Bravo, M. (2021). Trayectorias de la gobernanza de los recursos naturales en la Selva Central del Perú. In G. Damonte, B. Göbel, M. Paredes, B. Schorr, \& G. Castillo (Eds.), ¿Una oportunidad perdida? Boom extractivo y cambios institucionales en el Perú (pp. 189-222). Fondo Editorial, Pontificia Universidad Católica del Perú; Ibero-Amerikanisches Institut.

Brinks, D. M. (2008). The judicial response to police killings in Latin America. Cambridge University Press. https://doi.org/10.1017/CBO9780511551130

Brinks, D. M., Levitsky, S., \& Murillo, M. V. (Eds.). (2019). Understanding institutional weakness. Cambridge University Press. https://doi.org/10.1017/9781108772211

Brinks, D. M., Levitsky, S., \& Murillo, M. V. (Eds.). (2020). The politics of institutional weakness in Latin America. Cambridge University Press. https://doi.org/10.1017/9781108776608

Brollo, F., Nannicini, T., Perotti, R., \& Tabellini, G. (2013). The political resource curse. American Economic Review, 103(5), 1759-1796. https://doi.org/10.1257/aer.103.5.1759 
Brunnschweiler, C., \& Bulte, E. (2008). The resource curse revisited and revised: A tale of paradoxes and red herrings. Journal of Environmental Economics and Management, 55(3), $248-264$.

Bull, B., \& Aguilar-Støen, M. (2016). Changing elites, institutions and environmental governance. In F. de Castro, B. Hogenboom, \& M. Baud (Eds.), Environmental governance in Latin America (pp. 137-163). Palgrave Macmillan. https://doi.org/10.1007/978-1-137-50572-9_6

Cameron, P. D., \& Stanley, M. C. (2017). Oil, gas, and mining: A sourcebook for understanding the extractive industries. World Bank. https://doi.org/10.1596/978-0-8213-9658-2

Campbell, J. L. (2004). Institutional change and globalization. Princeton University Press. https:// doi.org/10.2307/j.ctv131bw68

Campbell, J. L. (2010). Institutional reproduction and change. In G. Morgan, J. L. Campbell, C. Crouch, O. K. Pedersen, \& R. Whitley (Eds.), The Oxford handbook of comparative institutional analysis. Oxford University Press.

Capoccia, G., \& Kelemen, R. D. (2007). The study of critical junctures: Theory, narrative, and counterfactuals in historical institutionalism. World Politics, 59(3), 341-369. https:// doi.org/10.1017/S0043887100020852

Cárdenas, J. (2020). Exploring the relationship between business elite networks and redistributive social policies in Latin American countries. Sustainability, 12(1), 13. https://doi. org/10.3390/su12010013

Caria, S. (2017). El petróleo en Ecuador, 2000-2015 ¿Maldición, bendición o simple recurso? Revista Iberoamericana de Estudios de Desarrollo, 6(2), 124-147. https://doi. org/10.26754/ojs_ried/ijds.248

Carrillo Hoyos, S. (2019). Extractive industry revenues and the subnational resource curse: The case of the Peruvian Andes. The Extractive Industries and Society, 6(4), 1134-1142. https://doi.org/10.1016/j.exis.2019.06.001

Caselli, F., \& Michaels, G. (2013). Do oil windfalls improve living standards? Evidence from Brazil. American Economic Journal: Applied Economics, 5(1), 208-238. https://doi.org/10.1257/app.5.1.208

CEPAL. (2019). Panorama social de América Latina 2018. Comisión Económica para América Latina y el Caribe (CEPAL). http://hdl.handle.net/11362/44395

Cesar, S., \& Jhony, O. (2020). Corporate social responsibility supports the construction of a strong social capital in the mining context: Evidence from Peru. Journal of Cleaner Production, 267, 122162. https://doi.org/10.1016/j.jclepro.2020.122162

Clark, T., \& North, L. (2018). Dominant elites in Latin America: From neo-liberalism to the 'pink tide'. Latin American political economy. Springer International Publishing. https://doi. org/10.1007/978-3-319-53255-4

Cord, L., Genoni, M. E., \& Rodriguez Castelan, C. (2015). Shared prosperity and poverty eradication in Latin America and the Caribbean. World Bank. http://hdl.handle.net/10986/21751

Crystal, J. (1990). Oil and politics in the Gulf. Cambridge University Press. https://doi.org/10.1017/ CBO9780511558818

Cuaresma, J. C., Oberhofer, H., \& Raschky, P. A. (2010). Oil and the duration of dictatorships. Public Choice, 148(3/4), 505-530. www.jstor.org/stable/41483710

Damonte, G. (2018). Mining formalization at the margins of the state: Small-scale miners and state governance in the Peruvian Amazon. Development and Change, 49(5), 1314-1335. https://doi.org/10.1111/dech.12414

Damonte, G. (2021). Limited state governance and institutional hybridization in alluvial ASM in Peru. Resources Policy, 72, 102118. https://doi.org/10.1016/j.resourpol.2021.102118

Damonte, G., Göbel, B., Paredes, M., Schorr, B., \& Castillo, G. (Eds.). (2021). ¿Una oportunidad perdida? Boom extractivo y cambios institucionales en el Perú. Fondo Editorial, Pontificia Universidad Católica del Perú; Ibero-Amerikanisches Institut. 
Dargent, E., Feldmann, A. E., \& Luna, J. P. (2017). Greater State capacity, lesser stateness: Lessons from the Peruvian commodity boom. Politics E Society, 45(1), 3-34. https://doi. org/10.1177/0032329216683164

Dargent, E., Orihuela, J. C., Paredes, M., \& Ulfe, M. E. (Eds.). (2017). Latin American political economy. Resource booms and institutional pathways: The case of the extractive industry in Peru. Palgrave Macmillan.

Delamaza, G., Maillet, A., \& Martínez Neira, C. (2017). Socio-territorial conflicts in Chile: Configuration and politicization (2005-2014). European Review of Latin American and Caribbean Studies, 104, 23-46. https://doi.org/10.18352/erlacs.10173

Della Porta, D., \& Tarrow, S. G. (2004). Transnational protest and global activism people, passions, and power. Rowman \& Littlefield.

Dickovick, J. T., \& Eaton, K. H. (2013). Latin America's resurgent centre: National government strategies after decentralization. Journal of Development Studies, 49(11), 1453-1466. https://doi.org/10.1080/00220388.2013.797073

Dietsche, E. (2007). Why the quality of institutions is not a cure for the "resource curse". The Journal of Energy and Development, 32(2), 262-282. www.jstor.org/stable/24813112

Dietz, K. (2019). Direct democracy in mining conflicts in Latin America: Mobilising against the La Colosa project in Colombia. Canadian Journal of Development, 40(2), 145-162. https://doi.org/10.1080/02255189.2018.1467830

Di John, J., \& Putzel, J. (2009). Political settlements. University of Birmingham. https://gsdrc. org/wp-content/uploads/2015/06/EIRS7.pdf

DiMaggio, P. J., \& Powell, W. W. (1983). The iron cage revisited: Institutional isomorphism and collective rationality in organizational fields. American Sociological Review, 48(2), 147-160. https://doi.org/10.2307/2095101

Dobbin, F., Simmons, B., \& Garrett, G. (2007). The global diffusion of public policies: Social construction, coercion, competition, or learning? Annual Review of Sociology, 33(1), 449-472. https://doi.org/10.1146/annurev.soc.33.090106.142507

Ducoing, C., Peres-Cajías, J., Badia-Miró, M., Bergquist, A.-K., Contreras, C., Ranestad, K., \& Torregrosa, S. (2018). Natural resources curse in the long run? Bolivia, Chile and Peru in the Nordic countries' mirror. Sustainability, 10(4), 965. https://doi.org/10.3390/ su10040965

Durand, F. (2016). Cuando el poder extractivo captura el estado: Lobbies, puertas giratorias y paquetazo ambiental en Perú. OXFAM.

Durand, F. (2019). La captura corporativa del estado en América Latina. trAndeS Working Paper Series No. 8. Lateinamerika-Institut, Freie Universität Berlin.

Falleti, T. G., \& Riofrancos, T. N. (2018). Endogenous participation: Strengthening prior consultation in extractive economies. World Politics, 70(1), 86-121. https://doi.org/10.1017/ S004388711700020X

Fernández, B., \& Garay, C. (2020). A multilevel approach to enforcement: Forest protection in the Argentine Chaco. In D. M. Brinks, S. Levitsky, \& M. V. Murillo (Eds.), The politics of institutional weakness in Latin America (pp. 183-207). Cambridge University Press.

Fligstein, N. (1996). Markets as politics: A political-cultural approach to market institutions. American Sociological Review, 61(4), 656-673. https://doi.org/10.2307/2096398

Flora, J. L., Flora, C. B., Campana, F., García Bravo, M., \& Fernández-Baca, E. (2006). Social capital and advocacy coalitions: Examples of environmental issues from Ecuador. In R. E. Rhoades (Ed.), Development with identity: Community, culture and sustainability in the Andes (pp. 287-297). CABI. https://doi.org/10.1079/9780851999494.0287

Frederiksen, T. (2018). Corporate social responsibility, risk and development in the mining industry. Resources Policy, 59, 495-505. https://doi.org/10.1016/j.resourpol.2018.09.004 
Fritz, B., \& Lavinas, L. (Eds.). (2015). A moment of equality for Latin America? Challenges for redistribution. Ashgate.

Gamu, J. K., \& Dauvergne, P. (2018). The slow violence of corporate social responsibility: The case of mining in Peru. Third World Quarterly, 39(5), 959-975. https://doi.org/10.1 080/01436597.2018.1432349

Gasparini, L., \& Cruces, G. (2013). Poverty and inequality in Latin America: A story of two decades. Journal of International Affairs, 66(2), 51-63. www.jstor.org/stable/24388285

Gilberthorpe, E., \& Papyrakis, E. (2015). The extractive industries and development: The resource curse at the micro, meso and macro levels. The Extractive Industries and Society, 2(2), 381-390. https://doi.org/10.1016/j.exis.2015.02.008

Grindle, M. S. (2004). Despite the odds: The contentious politics of education reform. Princeton University Press. www.jstor.org/stable/j.ctv36zq8d

Gustafsson, M.-T., Merino, R., \& Scurrah, M. (2020). Domestication of international norms for sustainable resource governance: Elite capture in Peru. Environmental Policy and Governance, 30(5), 227-238. https://doi.org/10.1002/eet.1904

Gylfason, T. (2011). Natural resource endowment: A mixed blessing. In R. Arezki, T. Gylfason, \& A. N. Sy (Eds.), Beyond the curse: Policies to harness the power of natural resource (pp. 7-34). IMF.

Haarstad, H., \& Fløysand, A. (2007). Globalization and the power of rescaled narratives: A case of opposition to mining in Tambogrande, Peru. Political Geography, 26(3), 289-308. https://doi.org/10.1016/j.polgeo.2006.10.014

Hall, K., Cleaver, F., Franks, T., \& Maganga, F. (2014). Capturing critical institutionalism: A synthesis of key themes and debates. European Journal of Development Research, 26, 71-86. http://doi.org/10.1057/ejdr.2013.48

Hall, P. A. (1986). Governing the economy: The politics of state intervention in Britain and France. Europe and the international order. Oxford University Press. www.loc.gov/catdir/enhancements/fy0603/86008654-d.html

Hall, P. A., \& Taylor, R. C. R. (1996). Political science and the three new institutionalisms. Political Studies, 44(5), 936-957. https://doi.org/10.1111/j.1467-9248.1996.tb00343.x

Hannan, M. T., \& Freeman, J. (1989). Organizational ecology. Harvard University Press.

Hanni, M., Jiménez, J. P., \& Ruelas, I. (2018). Regímenes fiscales vinculados a los recursos naturales no renovables en la región y su relación con el ciclo de precios: Evolución reciente y desafíos pendientes. Serie Macroeconomia de Desarrollo No. 195. CEPAL. https://repositorio. cepal.org/bitstream/handle/11362/44239/S1800993_es.pdf?sequence=1\&isAllowed=y

Haslam, P. (2016). Overcoming the resource curse: Reform and the rentier state in Chile and Argentina, 1973-2000. Development and Change, 47(5), 1146-1170. https://doi. org/10.1111/dech.12259

Haslam, P. (2021). The micro-politics of corporate responsibility: How companies shape protest in communities affected by mining. World Development, 139, 105322. https://doi. org/10.1016/j.worlddev.2020.105322

Haslam, P., \& Heidrich, P. (2018). The political economy of natural resources and development: From neoliberalism to resource nationalism. Taylor and Francis. http://gbv.eblib.com/patron/ FullRecord.aspx?p=4391725

Helmke, G., \& Levitsky, S. (2004). Informal institutions and comparative politics: A research agenda. Perspectives on Politics, 2(4), 725-740. www.jstor.org/stable/3688540

Helmke, G., \& Levitsky, S. (Eds.). (2006). Informal institutions and democracy: Lessons from Latin America. Johns Hopkins University Press.

Himley, M. (2012). Regularizing extraction in Andean Peru: Mining and social mobilization in an age of corporate social responsibility. Antipode, 45(2), 394-416. https://doi. org/10.1111/j.1467-8330.2012.01001.x 
Hinojosa, L. (2011). Riqueza mineral y pobreza en los Andes. The European Journal of Development Research, 23(3), 488-504. https://EconPapers.repec.org/RePEc:pal:eurjdr:v:23:y :2011:i:3:p:488-504

Holland, A. C. (2017). Forbearance as redistribution: The politics of informal welfare in Latin America. Cambridge University Press. https://doi.org/10.1017/9781316795613

Humphreys Bebbington, D., \& Bebbington, A. (2010). Anatomy of a regional conflict: Tarija and resource grievances in Morales's Bolivia. Latin American Perspectives, 37(4), 140-160. https://doi.org/10.1177/0094582X10372503

Hunter, W. (2021). Diffusion dynamics. In D. Kapiszewski, S. Levitsky, \& D. J. Yashar (Eds.), The inclusionary turn in Latin American democracies (pp. 93-116). Cambridge University Press. https://doi.org/10.1017/9781108895835.004

Karl, T. L. (1997). The paradox of plenty: Oil booms and petro-states. University of California Press. http://hdl.handle.net/2027/heb.31620.0001.001

Karl, T. L. (2007). Ensuring fairness: The case for a transparent fiscal social contract. In M. Humphreys, J. Sachs, \& J. E. Stiglitz (Eds.), Initiative for policy dialogue at Columbia. Escaping the resource curse. Columbia University Press.

Kaup, B. Z. (2010). A neoliberal nationalization? Latin American Perspectives, 37(3), 123-138. https://doi.org/10.1177/0094582X10366534

Keck, M. E., \& Sikkink, K. (1998). Activists beyond borders: Advocacy networks in international politics. Cornell University Press. www.jstor.org/stable/10.7591/j.ctt5hh13f

Khan, M. H. (2018). Political settlements and the analysis of institutions. African Affairs, 117(469), 636-655. https://doi.org/10.1093/afraf/adx044

Knight, J. (1992). Institutions and social conflict. Cambridge University Press. https://doi. org/10.1017/CBO9780511528170

Kolb, F. (2007). Protest and opportunities: The political outcomes of social movements. Campus.

Kolstad, I., \& Wiig, A. (2009). It's the rents, stupid! The political economy of the resource curse. Energy Policy, 37(12), 5317-5325. https://doi.org/10.1016/j.enpol.2009.07.055

Kuecker, G. D. (2007). Fighting for the forests: Grassroots resistance to mining in northern Ecuador. Latin American Perspectives, 34(2), 94-107. www.jstor.org/stable/27648012

Kurtz, M. J. (2013). Latin American state-building in comparative perspective. Cambridge University Press. https://doi.org/10.1017/CBO9781139019668

Kurtz, M. J., \& Brooks, S. M. (2011). Conditioning the "resource curse": Globalization, human capital, and growth in oil-rich nations. Comparative Political Studies, 44(6), 747770. https://doi.org/10.1177/0010414011401215

Kurzman, C. (1996). Structural opportunity and perceived opportunity in social-movement theory: The Iranian revolution of 1979. American Sociological Review, 61(1), 153-170. https://doi.org/10.2307/2096411

Larsen, P. B. (2016). The "new jungle law": Development, indigenous rights and ILO Convention 169 in Latin America. Revue Internationale de Politique de Développement, 7.1. https://doi.org/10.4000/poldev.2220

Leal, P. A. (2007). Participation: The ascendancy of a buzzword in the neo-liberal era. Development in Practice, 17(4/5), 539-548. www.jstor.org/stable/25548251

Lederman, D., \& Maloney, W. F. (2009). In search of the missing resource curse. Economía, 9(1), 1-56. https://doi.org/10.1353/eco.0.0012

Leiva, F. I. (2019). Economic elites and new strategies for extractivism in Chile. European Review of Latin American and Caribbean Studies, 108, 131-152. https://doi.org/10.32992/ erlacs. 10511

Lipsky, M. (1968). Protest as a political resource. American Political Science Review, 62(4), 1144-1158. https://doi.org/10.2307/1953909 
López-Calva, L. F., \& Lustig, N. (Eds.). (2010). Declining inequality in Latin America: A decade of progress? Brookings Institution Press. www.jstor.org/stable/10.7864/j.ctt6wpdkq

Luong, P. J., \& Weinthal, E. (2009). Oil is not a curse: Ownership structure and institutions in soviet successor States. Cambridge University Press. http://site.ebrary.com/lib/academiccompletetitles/home.action

Madariaga, A. (2018). From "green laggard" to regional leader: Explaining the recent development of environmental policy in Chile. Bulletin of Latin American Research, 38(4), 453-470. https://doi.org/10.1111/blar.12841

Madariaga, A., \& Allain, M. (2018). Contingent coalitions in environmental policymaking: How civil society organizations influenced the Chilean renewable energy boom. Policy Studies Journal, 48(3), 672-699. https://doi.org/10.1111/psj.12298

Mahdavy, H. (1970). The patterns and problems of economic development in rentier states: The case of Iran. In M. A. Cook (Ed.), Studies in the economic history of the Middle East: From the rise of Islam to the present day (pp. 428-467). Oxford University Press.

Mahoney, J. (2000). Path dependence in historical sociology. Theory and Society, 29(4), 507-548. www.jstor.org/stable/3108585

Mahoney, J. (2010). Colonialism and postcolonial development: Spanish America in comparative perspective. Cambridge University Press. www.h-net.org/reviews/showrev.php?id=33004

Mahoney, J., \& Thelen, K. A. (Eds.). (2010). Explaining institutional change: Ambiguity, agency, and power. Cambridge University Press.

Manzano, O., \& Gutiérrez, J. D. (2019). The subnational resource curse: Theory and evidence. The Extractive Industries and Society, 6(2), 261-266. https://doi.org/10.1016/j. exis.2019.03.010

Mazmanian, D. A., \& Sabatier, P. A. (1983). Implementation and public policy. Scott Foresman and Co.

McNulty, S. (2012). An unlikely success: Peru's top-down participatory budgeting experience. Journal of Public Deliberation, 8(2). https://doi.org/10.16997/jdd.146

Mehlum, H., Moene, K., \& Torvik, R. (2006). Institutions and the resource curse. The Economic Journal, 116(508), 1-20. https://doi.org/10.1111/j.1468-0297.2006.01045.x

Menaldo, V. (2016). The institutions curse. Cambridge University Press. https://doi. org/10.1017/CBO9781316481530

Méndez, J. E., O’Donnell, G. A., \& Pinheiro, P. S. (Eds.). (1999). The (un)rule of law and the underprivileged in Latin America. University of Notre Dame Press.

Moore, J., \& Velásquez, T. (2011). Sovereignty negotiated: Anti-mining movements, the state and multinational mining companies under Correa's '21st century socialism. In A. Bebbington (Ed.), Social conflict, economic development and the extractive industry: Evidence from South America. Taylor \& Francis.

Moore, M. (2004). Revenues, state formation, and the quality of governance in developing countries. International Political Science Review, 25(3), 297-319. https://doi. org/10.1177/0192512104043018

Murillo, M. V. (2009). Political competition, partisanship, and policy making in Latin American public utilities. Cambridge University Press. https://doi.org/10.1017/CBO9780511813092

North, D. C. (1990). Institutions, institutional change and economic performance. Cambridge University Press. https://doi.org/10.1017/CBO9780511808678

O'Donnell, G. (1993). On the State, democratization and some conceptual problems: A Latin American view with glances at some postcommunist countries. World Development, 21(8), 1355-1369. https://doi.org/10.1016/0305-750x(93)90048-e

OECD. (2004). Lessons learned on donor support to decentralization and local governance. OECD. www.oecd.org/dac/evaluation/30395116.pdf 


\section{Bettina Schorr and Gerardo Damonte}

Olesen, T. (Ed.). (2010). Rethinking globalizations. Routledge.

Orihuela, J. C. (2013). How do "Mineral-States" learn? Path-dependence, networks, and policy change in the development of economic institutions. World Development, 43, 138-148. https://doi.org/10.1016/j.worlddev.2012.10.004

Orihuela, J. C. (2014). Converging divergence: The diffusion of the green state in Latin America. Studies in Comparative International Development, 49(2), 242-265. https://doi. org/10.1007/s12116-013-9147-6

Orihuela, J. C. (2018). Institutions and place: Bringing context back into the study of the resource curse. Journal of Institutional Economics, 14(1), 157-180. https://doi.org/10.1017/ S1744137417000236

Orihuela, J. C., \& Granados, A. (2021). Institucionalidad ambiental minera: Entre el discurso legal y las prácticas de gobierno. In G. Damonte, B. Göbel, M. Paredes, B. Schorr, \& G. Castillo (Eds.), ¿Una oportunidad perdida? Boom extractivo y cambios institucionales en el Perú (pp. 157-188). Fondo Editorial, Pontificia Universidad Católica del Perú; Ibero-Amerikanisches Institut.

Orihuela, J. C., Mendieta, A., Pérez, C., \& Ramírez, T. (2021). From paper institutions to bureaucratic autonomy: Institutional change as a resource curse remedy. World Development, 143, 105463. https://doi.org/10.1016/j.worlddev.2021.105463

Orihuela, J. C., \& Paredes, M. (2017). Fragmented layering: Building a green state for mining in Peru. In E. Dargent, J. C. Orihuela, M. Paredes, \& M. E. Ulfe (Eds.), Resource booms and institutional pathways: The case of the extractive industry in Peru (pp. 97-117). Palgrave Macmillan.

Osorio, C. (2020). Conditional cash transfer programs in Ecuador and Chile. The role of policy diffusion. Palgrave Macmillan. https://doi.org/10.1007/978-3-030-51008-4

Paler, L. (2011). The subnational resource curse: Causes, consequences and prescriptions. Revenue Watch Institute. https://laurapaler.files.wordpress.com/2012/11/rwi_subnat_curse.pdf

Paler, L. (2013). Keeping the public purse: An experiment in windfalls, taxes, and the incentives to restrain government. American Political Science Review, 107(4), 706-725. https:// doi.org/10.1017/S0003055413000415

Palier, B. (2005). Ambiguous agreement, cumulative change: French social policy in the 1990s. In W. Streeck \& K. A. Thelen (Eds.), Beyond continuity: Institutional change in advanced political economies (pp. 127-144). Oxford University Press.

Paredes, M. (2016). The glocalization of mining conflict: Cases from Peru. The Extractive Industries and Society, 3(4), 1046-1057. https://doi.org/10.1016/j.exis.2016.08.007

Paredes, M., \& Schorr, B. (2021). Transformaciones institucionales ambiguas: La producción de mecanismos de participación y coerción para la gobernanza de las industrias extractivas. In G. Damonte, B. Göbel, M. Paredes, B. Schorr, \& G. Castillo (Eds.), ¿Una oportunidad perdida? boom extractivo y cambios institucionales en el Perú (pp. 97-128). Fondo Editorial, Pontificia Universidad Católica del Perú; Ibero-Amerikanisches Institut.

Perry, G., \& Olivera, M. (2009). El impacto del petróleo y la minería en el desarrollo regional y local en Colombia. CAF Documento de trabajo 2009/06. CAF. http://scioteca.caf.com/ handle/123456789/199

Peruzzotti, E. (2012). Broadening the notion of democratic accountability: Participatory innovation in Latin America. Polity, 44(4), 625-642. https://doi.org/10.1057/ pol.2012.20

Peters, B. G. (2018). The politics of bureaucracy: An introduction to comparative public administration (7th ed.). Taylor \& Francis.

Piven, F. F., \& Cloward, R. A. (1979). Poor people's movements: Why they succeed, how they fail. Vintage Books.

Polga-Hecimovich, J. (Ed.). (2019). Oxford research encyclopedia of politics. Oxford University Press. 
Ponce, A. F., \& McClintock, C. (2014). The explosive combination of inefficient local bureaucracies and mining production: Evidence from localized societal protests in Peru. Latin American Politics and Society, 56(3), 118-140. https://doi.org/10.1111/j.1548-2456.2014.00243.x

Pressman, J. L., \& Wildavsky, A. B. (1984). Implementation: How great expectations in Washington are dashed in Oakland (3rd ed.). University of California Press.

Robinson, J. A., Torvik, R., \& Verdier, T. (2006). Political foundations of the resource curse. Journal of Development Economics, 79(2), 447-468. https://doi.org/10.1016/j. jdeveco.2006.01.008

Ross, M. L. (1999). The political economy of the resource curse. World Policy, 51, 297-322.

Ross, M. L. (2001). Does oil hinder democracy? World Politics, 53(3), 325-361. www.jstor. org/stable/25054153

Ross, M. L. (2015). What have we learned about the resource curse? Annual Review of Political Science, 18(1), 239-259. https://doi.org/10.1146/annurev-polisci-052213-040359

Sabatier, P. A. (2005). From policy implementation to policy change: A personal odyssey. In P. Maassen, A. Amaral, A. Arimoto, N. Cloete, D. Dill, J. Enders, P. Gumport, M. Henkel, G. Jones, Å. Gornitzka, \& M. Kogan (Eds.), Higher education dynamics. Reform and change in higher education (pp. 17-34). Springer Netherlands. https://doi.org/10.1007/1-4020-3411-3_2

Sabatier, P. A., \& Weible, C. M. (2007). The advocacy coalition framework: Innovations and clarifications. In P. A. Sabatier (Ed.), Theories of the policy process. Westview Press.

Sachs, J., \& Warner, A. (1999). The big rush, natural resource booms and growth. Journal of Development Economics, 59(1), 43-76. https://doi.org/10.3386/w5398

Sánchez-Ancochea, D. (2019). The surprising reduction of inequality during a commodity boom: What do we learn from Latin America? Journal of Economic Policy Reform, 43(6), 1-24. https://doi.org/10.1080/17487870.2019.1628757

Sarmidi, T., Hook Law, S., \& Jafari, Y. (2014). Resource curse: New evidence on the role of institutions. International Economic Journal, 28(1), 191-206. https://doi.org/10.1080/1 0168737.2013.787110

Saylor, R. (2014). State building in boom times: Commodities and coalitions in Latin America and Africa. Oxford University Press.

Schickler, E. (2001). Disjointed pluralism: Institutional innovation and the development of the U.S. Congress. Princeton University Press. www.jstor.org/stable/j.ctt7rr34

Schilling-Vacaflor, A., \& Eichler, J. (2017). The shady side of consultation: Tactics of "divide and rule" in Bolivia's resource extraction. Development and Change, 48(6), 1439-1463.

Schilling-Vacaflor, A., \& Flemmer, R. (2015). Conflict transformation through prior consultation? Lessons from Peru. Journal of Latin American Studies, 47(4), 811-839. https:// doi.org/10.1017/S0022216X15000826

Schorr, B. (2018). Oportunidades desiguales: Empresas y estado en conflictos sobre la minería en Chile. Estudios Atacameños, 57, 239-255.

Shafer, D. M. (1994). Winners and losers: How sectors shape the developmental prospects of states. Cornell University Press. www.jstor.org/stable/10.7591/j.ctv2n7fn1

Sheingate, A. (2010). Rethinking rules: Creativity and constraint in the U.S. House of Representatives. In J. Mahoney \& K. A. Thelen (Eds.), Explaining institutional change: Ambiguity, agency, and power (pp. 168-203). Cambridge University Press.

Sindzingre, A. (2006). The relevance of the concepts of formality and informality: A theoretical appraisal. In B. Guha-Khasnobis, R. Kanbur, \& E. Ostrom (Eds.), Linking the formal and informal economy (pp. 58-73.). Oxford University Press.

Soifer, H. D. (2015). State building in Latin America. Cambridge University Press. https://doi. org/10.1017/CBO9781316257289 


\section{Bettina Schorr and Gerardo Damonte}

Stampini, M., Robles, M., Sáenz, M., Ibarrarán, P., \& Medellín, N. (2016). Poverty, vulnerability, and the middle class in Latin America. Latin American Economic Review, 25(1), 112. https://doi.org/10.1007/s40503-016-0034-1

Stevens, P., \& Dietsche, E. (2008). Resource curse: An analysis of causes, experiences and possible ways forward. Energy Policy, 36(1), 56-65. https://doi.org/10.1016/j. enpol.2007.10.003

Streeck, W., \& Thelen, K. A. (Eds.). (2005a). Beyond continuity: Institutional change in advanced political economies. Oxford University Press.

Streeck, W., \& Thelen, K. A. (2005b). Institutional change in advanced political economies. In W. Streeck \& K. A. Thelen (Eds.), Beyond continuity: Institutional change in advanced political economies (pp. 1-39). Oxford University Press.

Sugawara, N. (2014). From volatility to stability in expenditure: Stabilization funds in resource-rich countries. IMF Working Paper No. 43. IMF. www.imf.org/external/pubs/ $\mathrm{ft} / \mathrm{wp} / 2014 / \mathrm{wp} 1443 . \mathrm{pdf}$

Tarrow, S. G. (2005). The new transnational activism. Cambridge University Press.

Tello, M. D. (2013). ¿Podemos hablar de una maldición de los recursos naturales en el Perú? Economía y Sociedad, 84, 42-48.

Thelen, K. (2004). How institutions evolve: The political economy of skills in Germany, Britain, the United States, and Japan. Cambridge University Press. https://doi.org/10.1017/ CBO9780511790997

Thorp, R., Battistelli, S., Guichaoua, Y., Orihuela, J. C., \& Paredes, M. (2012). The developmental challenges of mining and oil: Lessons from Africa and Latin America. Palgrave Macmillan.

Tilly, C., \& Tarrow, S. G. (2007). Contentious politics. Paradigm.

Tockman, J., \& Cameron, J. (2014). Indigenous autonomy and the contradictions of plurinationalism in Bolivia. Latin American Politics and Society, 56(3), 46-69. www.jstor.org/ stable/43284913

Tornell, A., \& Lane, P. R. (1999). The voracity effect. American Economic Review, 89(1), 22-46. https://doi.org/10.1257/aer.89.1.22

Torres Wong, M. (2018). Natural resources, extraction and indigenous rights in Latin America: Exploring the boundaries of environmental and state-corporate crime in Bolivia, Peru, and Mexico. Routledge.

Torvik, R. (2011). The political economy of reform in resource-rich countries. In R. Arezki, T. Gylfason, \& S. Amadou (Eds.), Beyond the curse: Policies to harness the power of natural resources (pp. 237-256). IMF. www.elibrary.imf.org/view/books/071/118189781616351458-en/11818-9781616351458-en-book.xml

Tsai, K. S. (2016). Adaptive informal institutions. In O. Fioretos, T. G. Falleti, \& A. Sheingate (Eds.), The Oxford handbook of historical institutionalism. Oxford University Press.

Urkidi, L. (2010). A glocal environmental movement against gold mining: Pascua-Lama in Chile. Ecological Economics, 70(2), 219-227. https://EconPapers.repec.org/RePEc:eee:ec olec:v:70:y:2010:i:2:p:219-227

Viale, C. (2019). ¿Qué diversificación económica queremos en los países andinos? Análisis comparado de políticas de diversificación económica: Reflexiones y nuevas propuestas. NRGI. https:// resourcegovernance.org/analysis-tools/publications/que-diversificacion-economicaqueremos-en-los-paises-andinos-analisis

Viale, C., Monge, C., Ballon, E., \& Molina, R. (2017). Minería y marcos institucionales en la región andina. El súper ciclo y su legado, o las difíciles relaciones entre políticas de promoción de la inversión minero-hidrocarburifera y las reformas institucionales. NRGI-GIZ.

Walter, M., \& Martinez-Alier, J. (2010). How to be heard when nobody wants to listen: Community action against mining in Argentina. Canadian Journal of Development Studies, 30(1-2), 281-301. https://doi.org/10.1080/02255189.2010.9669292 
Walter, M., \& Urkidi, L. (2017). Community mining consultations in Latin America (20022012): The contested emergence of a hybrid institution for participation. Geoforum, 84, 265-279. https://doi.org/10.1016/j.geoforum.2015.09.007

Weyland, K. (2006). Bounded rationality and policy diffusion: Social sector reform in Latin America. Princeton University Press.

Wingfield, S., Martínez-Moscoso, A., Quiroga, D., \& Ochoa-Herrera, V. (2021). Challenges to water management in Ecuador: Legal authorization, quality parameters, and sociopolitical responses. Water, 13(8), 1017. https://doi.org/10.3390/w13081017

Zhu, J., \& Wu, Y. (2014). Who pays more “tributes” to the government? Sectoral corruption of China's private enterprises. Crime, Law and Social Change, 61(3), 309-333. https://doi. org/10.1007/s10611-013-9504-4 